\title{
Readiness to Learn English for Early Childhood
}

\author{
Sri Sumarni ${ }^{\circledR}{ }^{\bowtie}$, Machdalena Vianty ${ }^{2}$, Windi Dwi Andika ${ }^{1}$ \\ Pendidikan Guru Pendidikan Anak Usia Dini, Universitas Sriwijaya, Indonesia(1) \\ Pendidikan Bahasa Inggris, Universitas Sriwijaya, Indonesia( ${ }^{(2)}$ \\ DOI: $\underline{10.31004 / \text { obsesi.v6i3.1805 }}$
}

\begin{abstract}
Teachers need to understand the factors that influence the readiness of early childhood to learn their new language, especially English, to avoid inappropriate stimulation practices. This study aimed to examine early childhood English learning readiness factors based on relevant theories and research results. This research method was a qualitative literature review study. The literature review consists of 70 references related to the topic of early childhood English. This research method is a qualitative literature review study. As a result, children's readiness to learn is influenced by internal and external factors. Internal factors include cognitive abilities, mastery of the initial language, mastery of a new language, namely English, emotional maturity, and intrinsic motivation. At the same time, the external factors that influence include extrinsic motivation, family, social culture environment, and stimulation by playing. The novelty is to identify the influence of children's readiness factors in learning English both inside and outside the child. As a result, the teacher can consider the readiness of the child to avoid mistakes in introducing English as a new language for early childhood.
\end{abstract}

Keywords: readiness to learn foreign languages; early English childhood; literature study.

\begin{abstract}
Abstrak
Pentingnya guru memahami faktor-faktor yang mempengaruhi kesiapan anak usia dini untuk belajar bahasa barunya yakni Bahasa Inggris, agar menghindarkan praktik stimulasi yang tidak sesuai. Tujuan penelitian ini mengkaji tentang faktor kesiapan belajar Bahasa Inggris anak usia dini berdasarkan teori dan hasil penelitian relevan. Metode penelitian ini adalah studi kajian pustaka kualitatif. Kajian Pustaka terdiri dari 70 referensi terkait topik Bahasa Inggris anak usia dini. Hasilnya menunjukan kesiapan belajar anak dipengaruhi oleh faktor internal dan eksternal. Faktor internal mencakup kemampuan kognitif, penguasaan Bahasa awal, Penguasaan Bahasa baru yaitu Bahasa Inggris, kematangan emosi dan motivasi intrinsic. Sedangkan faktor eksternalnya seperti motivasi ekstrinsik, keluarga, lingkungan sosial budaya, dan stimulasi melalui bermain. Kebaharuan penelitian ini mengidentifikasi pengaruh faktor kesiapan anak dalam belajar Bahasa Inggris baik dari dalam dan luar diri anak. Dampaknya guru dapat mempertimbangkan kesiapan diri anak agar menghindarkan kekeliruan dalam mengenalkan Bahasa Inggris sebagai Bahasa baru bagi anak usia dini.
\end{abstract}

Kata Kunci: kesiapan belajar bahasa asing; bahasa inggrisanak usia dini; studi kajian pustaka.

Copyright (c) 2021 Sri Sumarni, et al.

$\triangle$ Corresponding author:

Email Address: sri_sumarni@fkip.unsri.ac.id (Palembang, Sumatera Selatan, Indonesia)

Received 14 May 2021, Accepted 23 September 2021, Published 27 September 2021 


\section{INTRODUCTION}

English is an international language used by people in the world to communicate between countries of different languages. Therefore, English is a highly recommended language to be mastered by Indonesian citizens. Indonesians who master English will have easy access to interact, communicate, and explore information from various parts of the world. This ease of access creates a paradigm that makes Indonesian parents introduce English to their children early. Various bilingual literature for children is sold in various bookstores throughout Indonesia and the proliferation of shows in English for children (Firdaus \& Muryanti, 2020; Liyana \& Kurniawan, 2019; Ulya \& Hasanah, 2013).

Learning English is not an easy matter. It is considered that English is a new language for early childhood. In early childhood, children have not fully mastered their initial language or Indonesian fluently, while a new language is introduced to children. Learning English has also become a controversy because, in several cases, it was found that there was "delay speech" experienced by Indonesian children. Learning Bahasa and English is due to the confusion of children learning the language (Dahniarti et al., 2019; Nugraha et al., 2019; Puspita et al., 2019; Tan et al., 2019)

Whereas according to language acquisition theory, early childhood has a Learning Acquisition Device (LAD). This theory asserts that every child has a language device in the brain from birth to learn the language. Children only need to practice their language skills. Children will more readily accept their new language after three years. This age is because, at this age, the child's initial language mastery is better (Singh \& Seet, 2019). Other research states the readiness of children to acquire a new language is about $50 \%$ (Wulandari, 2018). Other opinion states that the age of 8 years is the readiness of children to acquire new languages to reach $80 \%$ (Rakaiza Imani Nasuha, 2020). The fundamental difference between these theories is not the main focus because the most important thing is that the earlier a new language is learned before entering puberty, the easier it is for children to learn it. Research adults who learn a new language are not interactive, so early years is the ideal age to learn English (Kong, 2021).

Children's new language acquisition is not automatically obtained without stimulation and practice. It is not enough to communicate with speakers, and early childhood needs stimulation so that LAD can function optimally. Various references from books are reviewed, and journals will be reviewed to review this essay that discusses Second Language Acquisition (Saville, 2012). The book provides information about factors that must be considered when teaching children to acquire a new language, such as psychological aspects and in the child's social context. Reviewing from a psycholinguistic point of view concluded that learners are interactive and sweet because they are influenced by different factors: the learning context (Kootstra et al., 2015; L. J. Zhang \& Shen, 2020).

Various previous studies have stated that stimulation affects the acquisition of a second language in early childhood (Rakaiza Imani Nasuha, 2020; Suardi et al., 2019; Wulandari, 2018). Furthermore, Research findings state that there is a similarity factor between the first language and the second language and the learning context also has an effect (Ou et al., 2020). The age at which the child learns the language and the child's background are also important factors in acquiring a new language (Kootstra et al., 2015). Research looks at this more broadly by identifying the differences in the influence of external and internal factors on the acquisition of the second language of children, especially English which focuses on vocabulary and morphology quantitatively (Paradis, 2011).

Age differences related to motivation to learn English, including attitudes, self, and motivation in learning English (Kormos, 2008). The research examines the provision of Mother Language activities programs on children's reading readiness levels and heterogeneity in children learning multiple languages and examines readiness to learn English and Spanish at the end of the school year (Şimşek \& Alisinanoğlu, 2009; López \& Foster, 2021). 
The differences between this study and previous studies include: (1) This study aims to examine the factors that influence the readiness of early childhood to learn English. (2) This type of research is a qualitative literature study because the previous research was quantitative and case studies. (3) This research is a preliminary study in the manufacture of an instrument product for Early Childhood English Learning readiness. (4) This study examines 70 references consisting of journals, proceedings from various research results and books, as well as encyclopaedias. The research aimed to examine early childhood English learning readiness factors based on relevant theories and research results.

\section{METHOD}

The research method used is qualitative with a literature review approach. The rationale for using this method is appropriate to the research objectives that examine the literature. The factors that influence early childhood readiness to learn English (Ardoin \& Bowers, 2020). Researchers examined the contents of various books and the results of research in journals of 70 references. Sources are categorized into primary and secondary sources. Primary sources consist of two books, two encyclopaedias, 14 National Journals, 30 International Journals, two National Proceedings, and two International Proceedings. Secondary sources consist of sources obtained from three bibliographies, five from catalogues, and 10 abstracts. Data collection period from February to May. June to September analysis process after the data is displayed before concluding. Methods for collecting data sources are: keyword search, term subject search, search for the latest scientific papers, and search for other sources in scientific sources. The examined sources are relevant to the research topic: the readiness to learn English for early childhood. Checking the validity of the data (Bengtsson, 2016; Carter et al., 2014) was carried out in 3 stages, including data reduction, data display, and concluding. The research flow can be illustrated in chart 1.

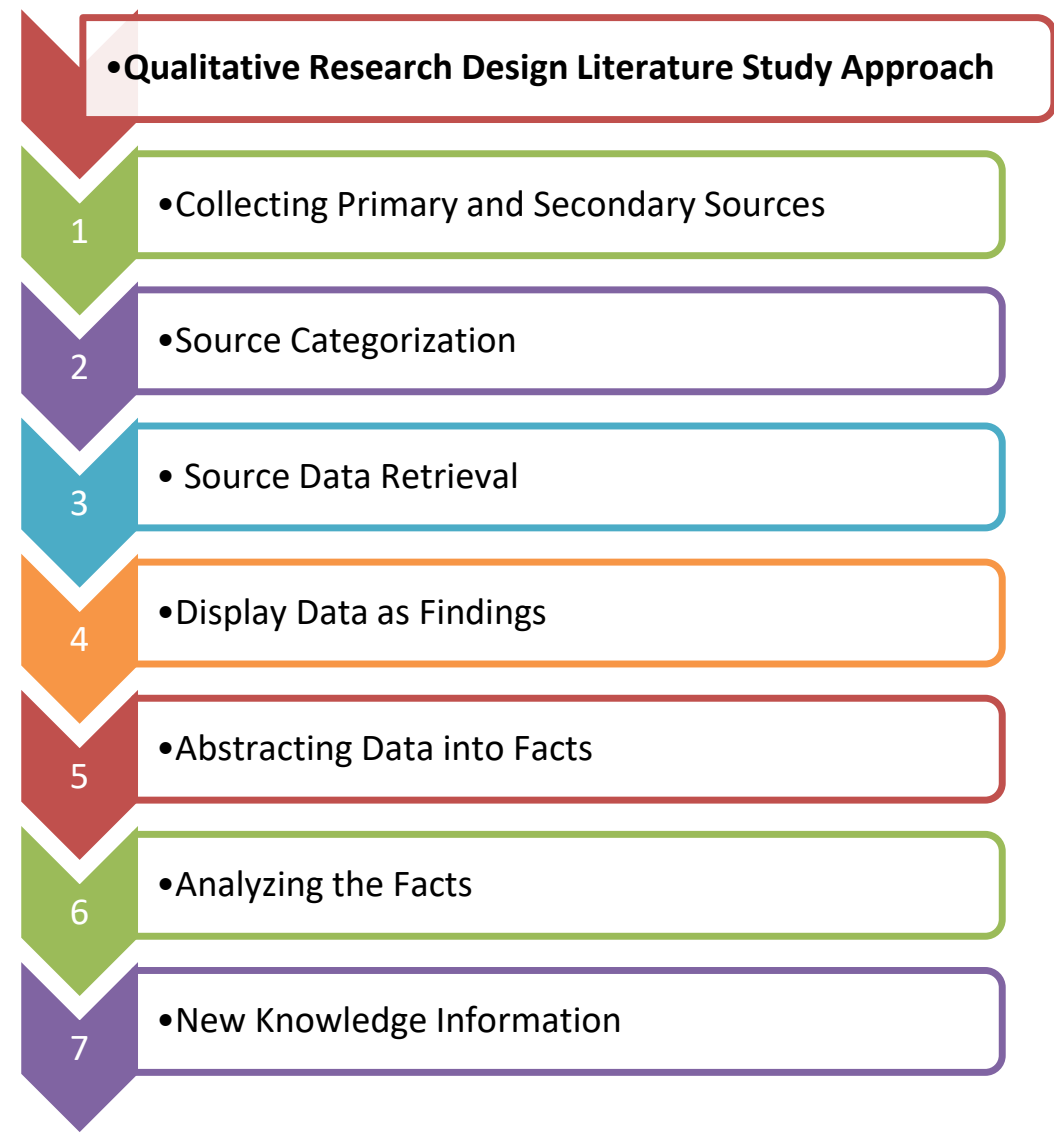

Chart 1. Research Flow (Snyder, 2019) 


\section{RESULT AND DISCUSSION}

The results of the study are based on the literature study approach. The content analysis results of various sources of primary and secondary libraries are categorized to become new knowledge information. The following is an illustration of the process of obtaining information on new findings in chart 2.

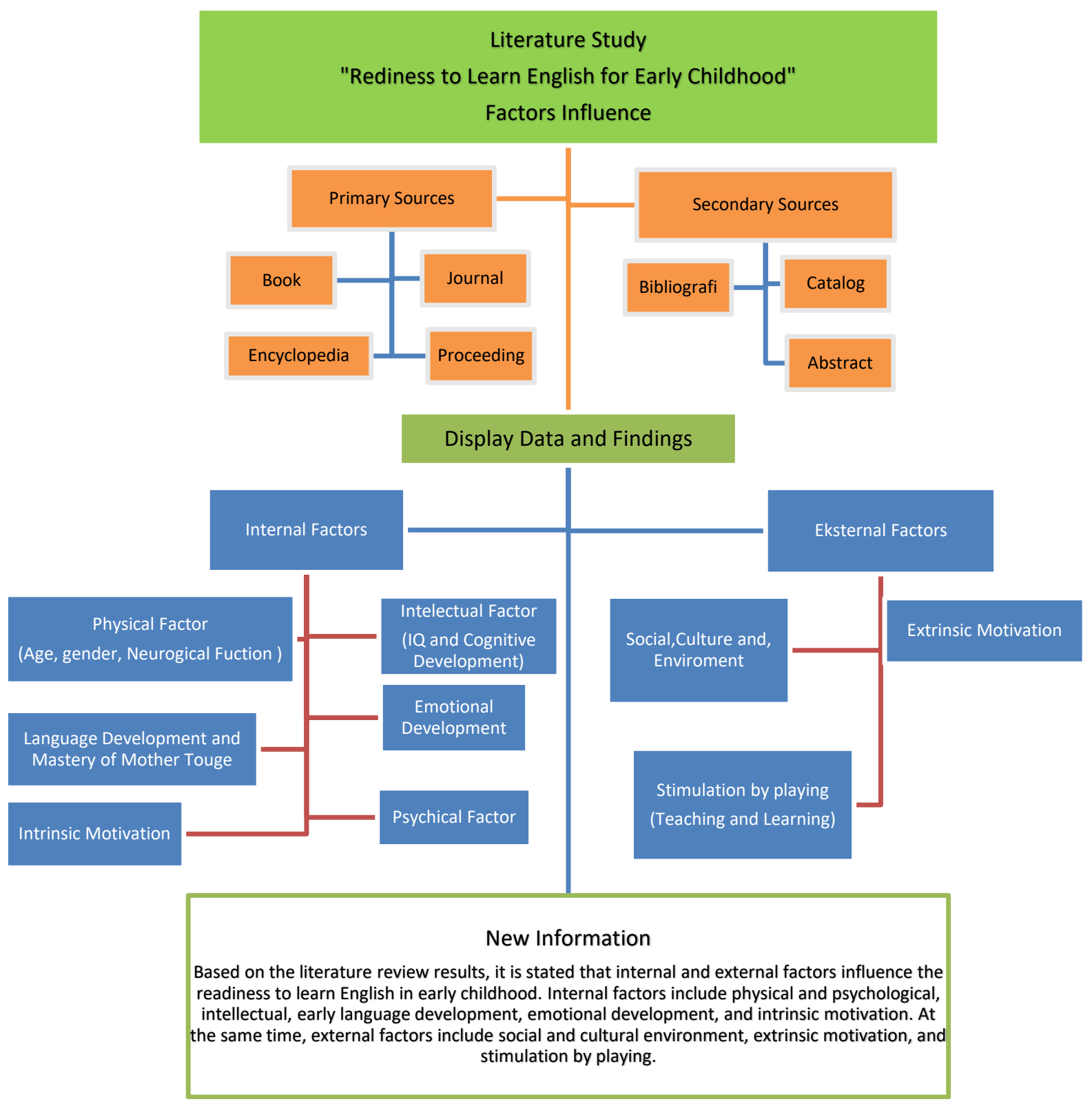

\section{Chart 2. Research Result}

The chart 3 shows that the research findings were obtained from the analysis of various literature: (1) Primary literature sources in the form of research results originating from journals and proceedings are open access. In contrast, primary literature sources in the form of theories or the basics of experts' thoughts are sourced from books and encyclopedias that are relevant to the readiness to learn English at an early age. (2) Secondary sources in reference search result from Bibliography, while search results from keywords come from catalogs. 


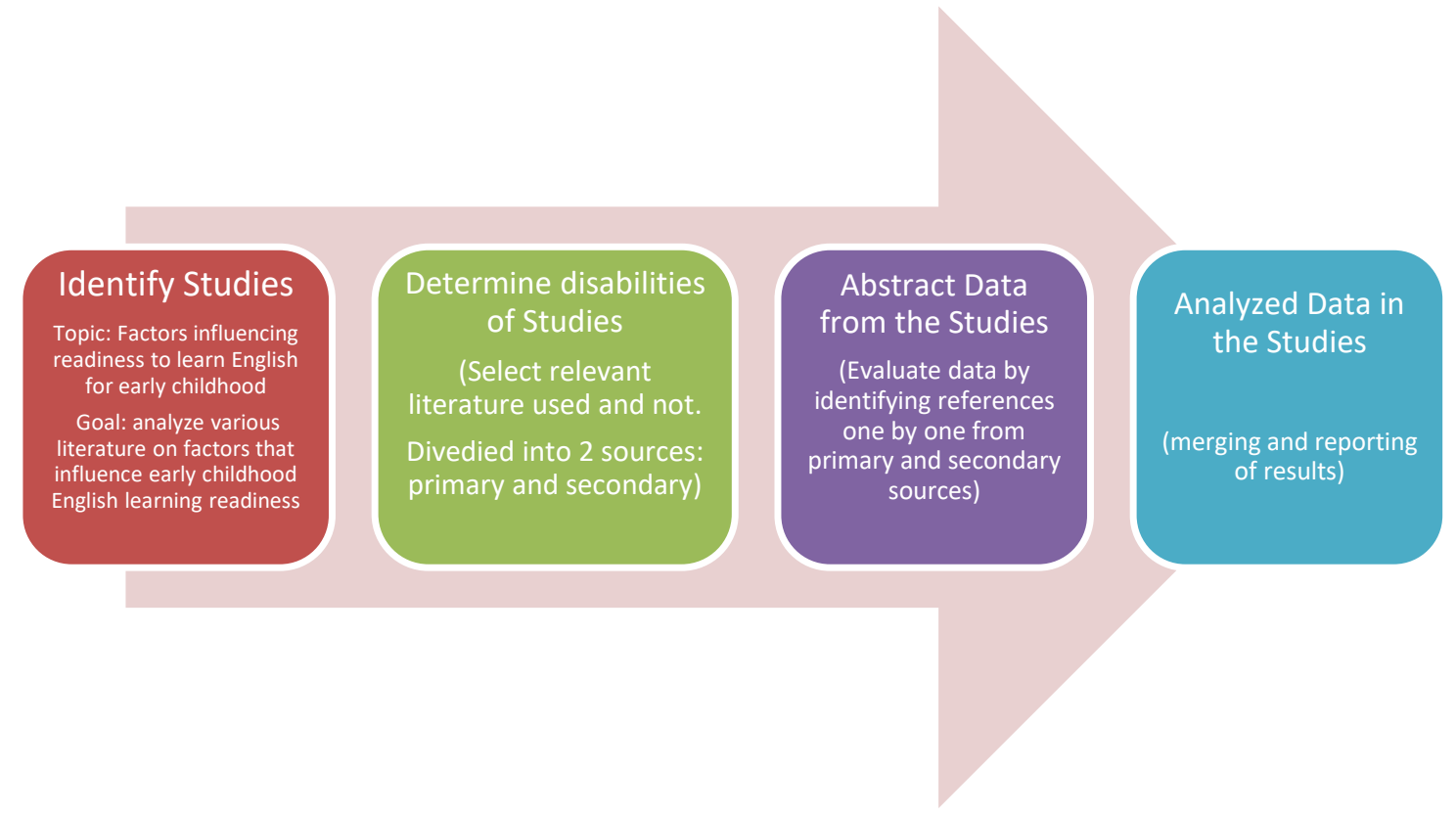

Chart 3. Implementation of Systematic Review

The implementation of the literature analysis process goes through four stages: First, the identification stage is the stage where the researcher sets the topic and research objectives. This research topic is about the factors that affect the readiness to learn English in early childhood. Meanwhile, the research objective is to analyze various literature on the topic. After the topic and objectives are determined, the second stage is to determine the disabilities of studies. This stage is the stage where the researcher selects the relevant literature that will be used. Then categorize the literature into two sources, namely primary and secondary sources. The graph 1 describes the results of the distribution of the number of references in each type of literature source. The primary source is shown by a blue bar graph, while a red bar graph shows a secondary source.

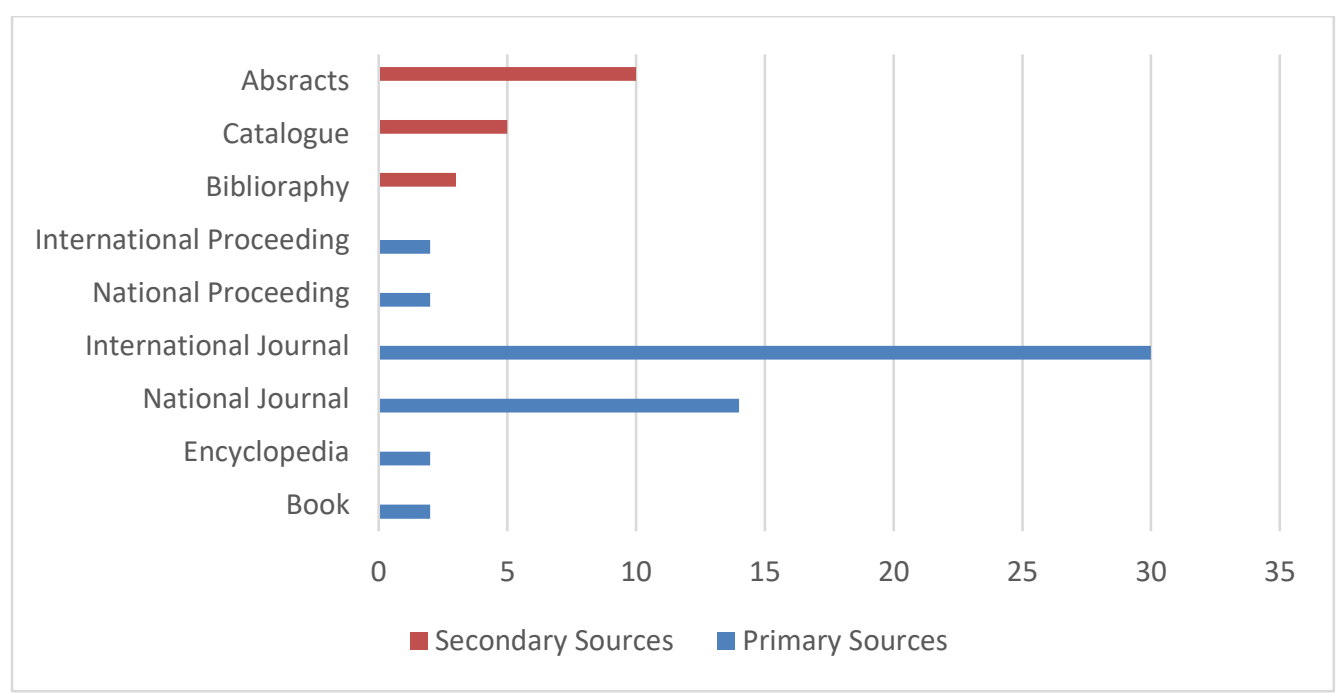

Graph 1. Graph of Categorization of Literature Sources

After that, the data abstraction stage evaluates the data by identifying references one by one from both primary and secondary sources. This stage is carried out to identify the relevance of the findings regarding factors related to the readiness to learn English for early childhood. The fourth stage, namely the data analysis stage, analyzes research findings and 
reports research results. The results discuss the factors that affect the readiness of early childhood to learn English, divided into two factors, including internal and external factors. The analysis table can be seen in table 1.

Table 1. Table of Analysis

\begin{tabular}{|c|c|c|c|}
\hline \multirow[t]{2}{*}{ No. } & \multirow[t]{2}{*}{ All sources } & \multicolumn{2}{|c|}{ Overall Findings } \\
\hline & & Internals Factors & Externals Factors \\
\hline 1 & Book & Language Development & Socioeconomic \\
\hline 2 & Encyclopedia & Language Development & \\
\hline 3 & International Journal & $\begin{array}{l}\text { Physical, Neurological, Age, } \\
\text { Physiological, Cognitive } \\
\text { Development, Early Language } \\
\text { Development, Intellectual, } \\
\text { Emotional Development, } \\
\text { Intrinsic Motivation, Gender }\end{array}$ & $\begin{array}{l}\text { Social Economic, } \\
\text { Environment, Extrinsic } \\
\text { Motivation, Stimulations }\end{array}$ \\
\hline 4 & National Journal & Cognitive Development & $\begin{array}{l}\text { Stimulations, Social } \\
\text { Economic, Culture }\end{array}$ \\
\hline 5 & $\begin{array}{l}\text { International } \\
\text { Proceeding }\end{array}$ & Early Language Development & Stimulations \\
\hline 6 & National Proceeding & Physical Development & Stimulations \\
\hline 7 & Bibliography & $\begin{array}{l}\text { Emotional Development, } \\
\text { Intellectual, Cognitive } \\
\text { Development, }\end{array}$ & Stimulations \\
\hline 8 & Catalogue & Early Language Development, & Stimulations \\
\hline 9 & Abstracts & $\begin{array}{l}\text { Emotional Development, } \\
\text { Physical, Cognitive } \\
\text { Development, Language } \\
\text { Development }\end{array}$ & $\begin{array}{l}\text { Stimulations, Culture, } \\
\text { Extrinsic Motivation }\end{array}$ \\
\hline
\end{tabular}

The results discuss the factors that affect the readiness of early childhood to learn English which is divided into two factors, including internal and external factors

\section{Internal Factors}

Internal Factors are factors that originate within the child to influence the readiness of early childhood to learn English (Pham \& Tipton, 2018).. Internal factors include physical and psychological, intellectual, early language development, emotional development, and intrinsic motivation. Physiological factors are closely related to the child's age, gender, and neurological function (Bradshaw et al., 2020). The child's age readiness in learning English determines how ready the child is to learn a new language. Experts state that early childhood readiness at the age of 3 years reaches $50 \%$, while the age of 8 years reaches $80 \%$.

Not only age, but another equally influential thing is also gender. Furthermore, the expert stated that girls are faster and more responsive in responding to information and reproduce it in expressive language than boys. Language is due to differences in the structure of the brains of boys and girls. Girls' brain structure develops faster in the language aspect than boys. According to experts, the limitations of neurological function will affect the maturity of the child's physical development, so that the impact is that children can experience disturbances and hinder language development (Vassar et al., 2020).

Intellectual factors also influence the readiness of children to learn English (Giroud et al., 2020). Intellectual factors can also affect how children learn a language (Grogan et al., 2012; Yellamsetty \& Bidelman, 2019). Children who have an average IQ need more time to understand the contents of the reading compared to children with a high IQ (Bonifacci \& Tobia, 2016). Children with high IQ tend to understand the meaning of reading faster. Then (Horbach et al., 2015) proved his study of the role of serial processing that has just studied 
sound-symbol associations in initial reading acquisition. In addition, children's cognitive development will also automatically affect children whose cognitive development is good. Their mastery of English in memorizing vocabulary and morphology will be even better (Espinosa, 2012).

Factors of early language development of children have a significant influence(Zein et al., 2020). Children will learn their mother tongue during the first three years until they can speak clearly and use much vocabulary when speaking (Vanbinst et al., 2020). If the child has not mastered the mother tongue, this will negatively impact if the child is taught a new language, namely English. The reason is that children experience confusion in using vocabulary in communication (Washington-Nortey et al., 2020), so the impact is a delay in language development (Panlilio \& Jones, 2017). In addition, children's language development has the same effect on children's readiness to read (Stern et al., 2018; Aram et al., 2014; S. Suggate et al., 2018; G. B. Thompson et al., 2015; Niklas et al., 2018; Majzub \& Kurnia, 2010), children's readiness in speaking aspects (Linklater et al., 2009), children's readiness in writing (Zhang \& Bingham, 2019; Bingham et al., 2017; Wang et al., 2015), readiness children in speaking and listening (Schaars et al., 2019).

Emotional development turns out to significantly influence school children's readinessChildren's (Niklas et al., 2018). In early childhood, the child's emotional state is very dependent on the situation. In addition, their symbolic way of thinking causes early childhood emotions to be unstable. Children are still in the stage of recognizing emotions in themselves, so they need emotional maturity when they mispronounce vocabulary and be persistent in learning English (Kang et al., 2014).

Intrinsic motivation is closely related to the emotional maturity of children while learning. Intrinsic motivation is an interest that originates in children to want to learn English willingly and without coercion (Hu \& Mcgeown, 2020; Jeong \& Lee, 2014; Nakamura, 2019; Oakes, 2013). If the child is interested in learning English, then the child will enjoy the way the teacher teaches and what material will be studied. Children will also spend more time exploring various learning resources such as English books and videos.

Psychological factors are also factors that have a strong influence on early childhood reading skills (Getie, 2020). These factors include motivation, children's interest in books (Capellini \& Germano, 2015), letters and other language symbols, and the child's selfadjusting attitude (Novén et al., 2021).

\section{External Factors}

External factors are factors that come from outside the child to influence the readiness of early childhood to learn English. External factors include social and cultural environment, extrinsic motivation, and stimulation by playing. Environmental factors have a significant influence on learning English (Dary, 2019). Social and cultural influence also affect children's language mastery. If children are in a socio-cultural environment conducive to learning English, of course, this will affect their mastery of language skills and vice versa.

Motivation affects the mastery of English (ChengChiang Chen \& Kent, 2020). Parents' motivation (Brien, 2020) towards reading makes children accustomed to books, so their interest in reading is undoubtedly better than children whose environment is not supportive (Ebert, 2020; Bojczyk et al., 2016 ). Parents who provide facilities for children to read at home will also significantly influence reading mastery in early childhood. (Solheim et al., 2018) stated that a harmonious family makes children's self-esteem positive, so parents tend to give affection and prepare their children well. The family affects children's reading ability. Extrinsic motivation influences children's readiness to learn a language (Griskell et al., 2020; Kormos \& Kiddle, 2013).

Environmental factors have an influence, one of which is the acquisition of children in learning English Vocabulary (Afzali \& Izadpanah, 2021). Socio-economic factors also affect the mastery of English (Kormos \& Kiddle, 2013; Liang et al., 2020) the establishment of children to 
practice speaking and reading skills in English (Bonifacci \& Tobia, 2016). People who come from an upper economic background will speak more verbally than people from a weak economy. The language used is academic, and they can put the correct vocabulary in the right conditions (Castro et al., 2017).

Culture and language are inseparable units, and culture has many positive impacts on one's language development. Culture teaches a person to interact with his environment. Culture also affects the mastery of English (Kizi \& Ugli, 2020). Culture has strong relevance in learning English (Riadini \& Cahyono, 2021). The importance of introducing the culture that exists in children when learning English. The impact avoids children's misunderstandings in communicating and interacting in the future.

Stimulation through play also affects children's readiness to learn English (Xu et al., 2021 Murdoch et al., 2021; Casillas et al., 2021). Other research in connectionism theory can be applied in stimulating English learning. Stimulation in Learning English is closely related to teaching and learning. In detail, we will discuss the essential components in the process of teaching and learning. Firstly is the curriculum, which provides meaningful and enjoyable learning experiences while learning English. Second, Methods are a way to learn the material. Third, the material presented is brief, precise, and applicable. Fourth is learning media that helps facilitate children so that learning material is presented concretely (Nurjati, 2016).

Research (Azizah, 2020) shows the influence of storybooks in acquiring the second language of children aged three years. Further stated (Tri et al., 2020), learning media also affects children's second language acquisition, namely English, one of which is learning videos (Dincer, 2020) for the introduction of English vocabulary (C. G. Thompson \& von Gillern, 2020). (Heritage et al., 2017) stated that the facilitator in learning English. The study limitation only analyzes literature from primary and secondary sources without including tertiary sources.

\section{CONCLUSION}

The conclusion is that introducing English to early childhood needs to consider internal and external factors that affect children's readiness, including physical, psychological, intellectual readiness, early language development, emotions, and motivation, socio-cultural environment, and stimulation programs. Research can provide positive benefits for parents, educators, and stakeholders in providing new information about the factors that affect children's readiness to learn English. This information relates to the proliferation of international PAUD schools that use the current bilingualism program. This benefit is relevant to the research objective to examine the factors that affect early childhood readiness in learning English as a new language.

\section{ACKNOWLEDGMENT}

The research/publication of this article was funded by DIPA of Public Service Agency of Universitas Sriwijaya 2021. SP DIPA-023.17.2.677515/2021, On November 23, 202. In accordance with the Rector's Decree Number: 0010/UN9/SK.LP2M.PT/2021, On April 28, 2021".

\section{REFERENCES}

Academy, A., Pediatrics, O. F., \& Overweight, P. (2003). Prevention of Pediatric Overweight and Obesity. Pediatrics, 112(2). https://doi.org/10.1542/peds.112.2.424

Afzali, Z., \& Izadpanah, S. (2021). The Effect of the Flipped Classroom Model on Iranian English foreign language learners: Engagement and Motivation in English language Grammar. Cogent Education, 8(1). https:// doi.org/10.1080/2331186X.2020.1870801

Aram, D., Korat, O., Saiegh-haddad, E., Hassunha, S., Khoury, R., \& Abu, J. (2014). Cognitive Development Early Literacy among Arabic-Speaking Kindergartners: The Role of 
Socioeconomic Status, Home Literacy Environment and Maternal Mediation of Writing. Cognitive Development, 28(3), 193-208. https:// doi.org/10.1016/j.cogdev.2012.10.003

Ardoin, N. M., \& Bowers, A. W. (2020). Early Childhood Environmental Education: A Systematic Review of the Research Literature. Educational Research Review, 100353. https:// doi.org/10.1016/j.edurev.2020.100353

Azizah, M. P. N. (2020). Pengaruh Buku Cerita Dalam Pemerolehan Bahasa Kedua Pada Anak Usia 3 Tahun. Jurnal Keilmuan Bahasa, Sastra, Dan Pengajarannya, 3(2), 2621-9042.

Bengtsson, M. (2016). How To Plan And Perform A Qualitative Study Using Content Analysis. NursingPlus Open, 2, 8-14. https:// doi.org/10.1016/j.npls.2016.01.001

Bingham, G. E., Quinn, M. F., \& Gerde, H. K. (2017). Early Childhood Research Quarterly Examining Early Childhood Teachers ' Writing Practices: Associations Between Pedagogical Supports and Children ' S Writing Skills. Early Childhood Research Quarterly, 39, 35-46. https:// doi.org/10.1016/j.ecresq.2017.01.002

Bojczyk, K. E., Davis, A. E., \& Rana, V. (2016). Early Childhood Research Quarterly Mother Child Interaction Quality In Shared Book Reading: Relation to Child Vocabulary and Readiness to Read. Early Childhood Research Quarterly, 36, 404-414. https:// doi.org/10.1016/j.ecresq.2016.01.006

Bonifacci, P., \& Tobia, V. (2016). Crossing Barriers: Profiles of Reading and Comprehension Skills in Early and Late Bilinguals, Poor Comprehenders, Reading Impaired, and Typically Developing Children. Learning and Individual Differences, 47, 17-26. https://doi.org/10.1016/j.lindif.2015.12.013

Bradshaw, M. J., Bhattacharyya, S., Venna, N., \& Cahill, J. F. (2020). Neurologic Manifestations of Systemic Rheumatologic Diseases. In Current Clinical Neurology (pp. 321-342). https:// doi.org/10.1007/978-3-030-24436-1_17

Brien, B. A. O. (2020). Child, Family, and School Factors in Bilingual Preschoolers' Vocabulary Development in Heritage Languages. Journal of Child Language, 47 (4), 817-843, 47, 817-843. https://doi.org/10.1017/S0305000919000904

Capellini, S. A., \& Germano, G. D. (2015). Early Identification of Reading Problems: Preliminary Study with Students of 1st Grade. Procedia - Social and Behavioral Sciences, 174, 1351-1355. https:// doi.org/10.1016/j.sbspro.2015.01.758

Carter, N., Bryant-Lukosius, D., Dicenso, A., Blythe, J., \& Neville, A. J. (2014). The Use of Triangulation in Qualitative Research. Oncology Nursing Forum, 41(5), 545-547. https:// doi.org/10.1188/14.ONF.545-547

Casillas, M., Brown, P., \& Levinson, S. C. (2021). Early Language Experience in A Papuan Community. Journal of Child Language, 48(4), 792-814. https:// doi.org/10.1017/S0305000920000549

Castro, D. C., Gillanders, C., Franco, X., Bryant, D. M., Zepeda, M., Willoughby, M. T., \& Méndez, L. I. (2017). Early Childhood Research Quarterly Early education of Dual Language Learners: An Efficacy Study of the School Readiness Professional Development Program Nuestros Ni nos. Early Childhood Research Quarterly, 40, 188203. https://doi.org/10.1016/j.ecresq.2017.03.002

ChengChiang Chen, J., \& Kent, S. (2020). Task Engagement, Learner Motivation and Avatar Identities of Struggling English language Learners in the 3D Virtual World. System, 88. https:// doi.org/10.1016/j.system.2019.102168

Dahniarti, C., Siti, M., \& Fajar, A. (2019). Flashcard for Enriching and Developing the Child Vocabulary with Speech Delay to Improve Lingual Skill. Dinamika Jurnal Ilmiah Pendidikan Dasar, 11(2), 100. https:// doi.org/10.30595/ dinamika.v11i2.5042

Dary, L. (2019). Heliyon Motivation and E-Learning English as a foreign language: A qualitative study. 5(August). https://doi.org/10.1016/j.heliyon.2019.e02394

Dincer, A. (2020). Understanding the Characteristics of English Language Learners' Out-ofClass Language Learning through Digital Practices Volume 8 - Issue 2 IAFOR Journal 
of Education: Technology in Education Volume 8 - Issue 2 IAFOR Journal of Education: Technology in. IAFOR Journal of Education: Technology in Education, 8(2), 47-65. https://doi.org/10.22492/ije.8.2.03

Ebert, S. (2020). Theory of Mind, Language, and Reading: Developmental Relations from Early Childhood To Early Adolescence. Journal of Experimental Child Psychology, 191, 104739. https:// doi.org/10.1016/j.jecp.2019.104739

Espinosa, L. (2012). Assessment of Young English-Language Learners. The Encyclopedia of Applied Linguistics. https:// doi.org/10.1002/9781405198431.wbeal0057

Firdaus, M., \& Muryanti, E. (2020). Games Edukasi Bahasa Inggris untuk Pengembangan Kosakata Bahasa Inggris pada Anak Usia Dini. Jurnal Pendidikan Tambusai, 4(2), 12161227. https://jptam.org/index.php/iptam/article/view/588

Getie, A. S. (2020). Factors Affecting The Attitudes of Students Towards Learning English as A Foreign Language. Cogent Education, 7(1). https:// doi.org/10.1080/2331186X.2020.1738184

Giroud, N., Baum, S. R., Gilbert, A. C., Phillips, N. A., \& Gracco, V. (2020). Brain and Language Earlier Age of Second Language Learning Induces More Robust Speech Encoding in The Auditory Brainstem in Adults, Independent Of Amount Of Language Exposure During Early Childhood. Brain and Language, 207(May), 104815. https://doi.org/10.1016/j.bandl.2020.104815

Griskell, H. L., Gámez, P. B., \& Lesaux, N. K. (2020). Learning and Individual Differences Assessing Middle School Dual Language Learners ' and English-Only Students ' Motivation to Participate in Classroom Discussion. Learning and Individual Differences, 77(October 2019), 101799. https:// doi.org/10.1016/j.lindif.2019.101799

Grogan, A., 'O. Parker Jones, T., Ali, N., Crinion, J., Orabona, S., Mechias, M. L., Ramsden, S., Green, D. W., \& Price, C. J. (2012). Structural Correlates for Lexical Efficiency and Number of Languages in Non-Native Speakers of English. Neuropsychologia, 50(7), 1347-1352. https://doi.org/10.1016/j.neuropsychologia.2012.02.019

Heritage, M., Walqui, A., Linquanti, R., \& Billings, E. (2017). Facilitators ' Guide For Discussion English Language Learners And The New Standards : Developing Language, Content Knowledge, and Analytical Practices In The Classroom.

Horbach, J., Scharke, W., Cröll, J., Heim, S., \& Günther, T. (2015). Kindergarteners' performance in a sound-symbol paradigm predicts early reading. Journal of $\begin{array}{llll}\text { Experimental Child } & \text { Psychology, 139, 256-264. }\end{array}$ https://doi.org/10.1016/j.jecp.2015.06.007

$\mathrm{Hu}$, X., \& Mcgeown, S. (2020). Exploring The Relationship Between Foreign Language Motivation and Achievement Among Primary School Students Learning English in China. System, 89, 102199. https://doi.org/10.1016/j.system.2020.102199

Jeong, E., \& Lee, E. (2014). Motivation, Investment, and Identity in English language Development: A longitudinal Case Study q. System, 42, 440-450. https://doi.org/10.1016/j.system.2014.01.013

Kang, H. S., Haddad, E., Chen, C., \& Greenberger, E. (2014). Limited English Proficiency and Socioemotional Well-Being Among Asian and Hispanic Children From Immigrant Families. Early Education and Development, 25(6), 915-931. https://doi.org/10.1080/10409289.2014.883664

Karimah, Ibrotul \& Komalasari, D. (2019). Literasi Pemerolehan Bahasa Kedua dalam Perkembangan Bahasa Anak Usia 5-6 Tahun. Jurnal PG PAUD UNESA, 148, 148-162.

Kizi, J. K. G., \& Ugli, M. K. S. (2020). Teaching Culture As A Tool To English Teaching Methodology. Science and Education, 1(3), 591-594. https://cyberleninka.ru/article/n/teaching-culture-as-a-tool-to-english-teachingmethodology 
Kong, S. (2021). Adult Mandarin Chinese Speakers' Acquisition of Locational and Directional Prepositional Constructions in Second Language English. Lingua, 249, 102993. https:// doi.org/10.1016/j.lingua.2020.102993

Kootstra, G. J., Dijkstra, T., \& Starren, M. (2015). Second Language Acquisition. In International Encyclopedia of the Social \& Behavioral Sciences: Second Edition (Second Edi, Vol. 21). Elsevier. https:/ / doi.org/10.1016/B978-0-08-097086-8.53025-6

Kormos, J., \& Kiddle, T. (2013). The Role Of Socio-Economic Factors In Motivation To Learn English As A Foreign Language: The Case Of Chile. System. https:// doi.org/10.1016/j.system.2013.03.006

Liang, L., Li, H., \& Chik, A. (2020). Two Countries, One Policy: A Comparative Synthesis Of Early Childhood English Language Education In China And Australia. Children and $\begin{array}{lll}\text { Youth Services } & 105386 .\end{array}$ https:// doi.org/10.1016/j.childyouth.2020.105386

Linklater, D. L., O'Connor, R. E., \& Palardy, G. J. (2009). Kindergarten Literacy Assessment Of English Only And English Language Learner Students: An Examination Of The Predictive Validity Of Three Phonemic Awareness Measures. Journal of School Psychology, 47(6), 369-394. https:// doi.org/10.1016/j.jsp.2009.08.001

Liyana, A., \& Kurniawan, M. (2019). Speaking Pyramid Sebagai Media Pembelajaran Kosa Kata Bahasa Inggris Anak Usia 5-6 Tahun. Jurnal Obsesi : Jurnal Pendidikan Anak Usia Dini, 3(1), 225. https://doi.org/10.31004/obsesi.v3i1.178

López, L. M., \& Foster, M. E. (2021). Examining Heterogeneity Among Latino Dual Language Learners' School Readiness Profiles Of English And Spanish At The End Of Head Start. Journal of Applied Developmental Psychology, 73(January). https:// doi.org/10.1016/j.appdev.2021.101239

Majzub, R., \& Kurnia, R. (2010). Reading Readiness Amongst Preschool Children In Pekanbaru Riau. 9, 589-594. https:// doi.org/10.1016/j.sbspro.2010.12.202

Nakamura, T. (2019). Understanding Motivation For Learning Languages Other Than English: Life Domains Of L2 Self. System, 82, 111-121. https://doi.org/10.1016/j.system.2019.03.006

Niklas, F., Cohrssen, C., Segerer, R., Schmiedeler, S., Galpin, R., Valeska, V., Kandler, S., \& Tayler, C. (2018). Early Childhood Professionals ' Perceptions Of Children ' S School Readiness Characteristics In Six Countries. 90(December 2017), 144-159. https:// doi.org/10.1016/j.ijer.2018.06.001

Novén, M., Olsson, H., Helms, G., Horne, M., Nilsson, M., \& Roll, M. (2021). Cortical And White Matter Correlates Of Language-Learning Aptitudes. Human Brain Mapping, June, 1-14. https://doi.org/10.1002/hbm.25598

Nugraha, A., Daniati, E., Susyanti, S., Patimah, I., \& Susani, E. (2019). The Experience of Parents with Speech Delayed Children in Garut, Indonesia. 203(Iclick 2018), 274-277. https:// doi.org/10.2991/iclick-18.2019.56

Nurjati, I. S. (2016). Teori Koneksionisme Dalam Pembelajaran Bahasa Kedua Anak Usia Dini. Journal Indonesia Language Education and Literature, 1(2), 207-220. https:// doi.org/10.24235/ileal.v1i2.599

Oakes, L. (2013). Foreign Language Learning In A ' Monoglot Culture ': Motivational Variables Amongst Students Of French And Spanish At An English University. System, 41(1), 178-191. https:// doi.org/10.1016/j.system.2013.01.019

Ou, J., Li, W., Yang, Y., Wang, N., \& Xu, M. (2020). Earlier Second Language Acquisition Is Associated With Greater Neural Pattern Dissimilarity Between The First And Second Languages. Brain and Language, 203(November 2019), 104740. https:// doi.org/10.1016/j.bandl.2019.104740

Panlilio, C. C., \& Jones, B. (2017). Child Abuse \& Neglect School Readiness Of Maltreated Preschoolers And Later School Achievement: The Role Of Emotion Regulation, Language , And Context. June, 1-10. https:// doi.org/10.1016/j.chiabu.2017.06.004 
Paradis, J. (2011). Individual Differences In Child English Second Language Acquisition Comparing Child-Internal And Child-External Factors. 3(2011), 213-237. https://doi.org/10.1075/lab.1.3.01par

Pham, G., \& Tipton, T. (2018). Internal And External Factors That Support Children's Minority First Language And English. Language, Speech, and Hearing Services in Schools, 49(3), 595-606. https://doi.org/10.1044/2018_LSHSS-17-0086

Puspita, A. C., Perbawani, A. A., Adriyanti, N. D., \& Sumarlam. (2019). Analisis Bahasa Lisan Pada Anak Keterlambatan Bicara. Jurnal Bahasa, Sastra, Dan Pengajarannya, 15(2), 154160.

Rakaiza Imani Nasuha, . (2020). Pengaruh Youtube Terhadap Permerolehan Bahasa Kedua Pada Anak Usia 8 Tahun. Jurnal Pendidikan Bahasa Dan Sastra Indonesia, 6(2), 44-59.

Riadini, U. S., \& Cahyono, B. Y. (2021). The Analysis of the Culture-Related Contents in an Indonesian English Textbook. 5(2), 285-295.

Saville, M. (2012). Introducing Second Language Acquisition (Second Edi).

Schaars, M. M. H., Segers, E., \& Verhoeven, L. (2019). Cognitive And Linguistic Precursors Of Early First And Second Language Reading Development. Learning and Individual Differences, 72(June 2018), 1-14. https:/ / doi.org/10.1016/j.lindif.2019.03.008

Şimşek, Ö., \& Alisinanoğlu, F. (2009). Examination Of The Effect Of Mother Tongue Activities Program On The Reading Readiness Level Of Preschool Children. Procedia - Social and Behavioral Sciences, 1(1), 521-528. https:// doi.org/10.1016/j.sbspro.2009.01.094

Snyder, H. (2019). Literature Review As A Research Methodology: An Overview And Guidelines. Journal of Business Research, 104(July), 333-339. https://doi.org/10.1016/j.jbusres.2019.07.039

Stern, J. M. B., Dubeck, M. M., \& Dick, A. (2018). Using Early Grade Reading Assessment (EGRA) Data For Targeted Instructional Support: Learning Profiles And Instructional Needs In Indonesia. International Journal of Educational Development, 61(March 2017), 64-71. https://doi.org/10.1016/j.ijedudev.2017.12.003

Suardi, I. P., Ramadhan, S., \& Asri, Y. (2019). Pemerolehan Bahasa Pertama Pada Anak Usia Dini. Jurnal Obsesi: Jurnal Pendidikan Anak Usia Dini, 3(1), 265. https://doi.org/10.31004/obsesi.v3i1.160

Suggate, S., Schaughency, E., McAnally, H., \& Reese, E. (2018). From Infancy To Adolescence: The Longitudinal Links Between Vocabulary, Early Literacy Skills, Oral Narrative, And Reading Comprehension. Cognitive Development, 47(October 2017), 82-95. https://doi.org/10.1016/j.cogdev.2018.04.005

Tan, S., Mangunatmadja, I., \& Wiguna, T. (2019). Risk Factors For Delayed Speech In Children Aged 1-2 Years. Paediatrica Indonesiana, 59(2), 55-62. https:// doi.org/10.14238/pi59.2.2019.55-62

Thompson, C. G., \& von Gillern, S. (2020). Video-Game Based Instruction For Vocabulary Acquisition With English Language Learners: A Bayesian Meta-Analysis. Educational $\begin{array}{lll}\text { Research } & \text { Review, 2019), } & 100332 .\end{array}$ https://doi.org/10.1016/j.edurev.2020.100332

Thompson, G. B., Fletcher-Flinn, C. M., Wilson, K. J., McKay, M. F., \& Margrain, V. G. (2015). Learning With Sublexical Information From Emerging Reading Vocabularies In Exceptionally Early And Normal Reading Development. Cognition, 136, 166-185. https://doi.org/10.1016/j.cognition.2014.11.032

Tri, L., Swastyastu, J., Visual, M., \& Pembelajaran, M. (2020). Manfaat Media Pembelajaran Dalam Pemerolehan. 5(1), 52-59.

Ulya, N., \& Hasanah, N. I. (2013). Strategi Pengenalan Bahasa Inggris Pada Anak Usia Dini Di TK Santa Maria Banjarmasin. Jurnal Warna: Jurnal Pendidikan Dan Pembelajaran Anak Usia Dini., 05(02), 57-68. https://doi.org/10.24903/jw.v5i2 
Vanbinst, K., van Bergen, E., Ghesquière, P., \& De Smedt, B. (2020). Cross-Domain Associations Of Key Cognitive Correlates Of Early Reading And Early Arithmetic In 5Year-Olds. Early Childhood Research Quarterly, 51, 144-152. https:// doi.org/10.1016/j.ecresq.2019.10.009

Vassar, R., Schadl, K., Cahill-Rowley, K., Yeom, K., Stevenson, D., \& Rose, J. (2020). Neonatal Brain Microstructure And Machine-Learning-Based Prediction Of Early Language Development In Children Born Very Preterm. Pediatric Neurology, 108, 86-92. https://doi.org/10.1016/j.pediatrneurol.2020.02.007

Wang, Y., Yin, L., \& Mcbride, C. (2015). Early Childhood Research Quarterly Unique Predictors Of Early Reading And Writing: A One-Year Longitudinal Study Of Chinese Kindergarteners. Early Childhood Research Quarterly, 32, 51-59. https:// doi.org/10.1016/j.ecresq.2015.02.004

Washington-Nortey, P. M., Zhang, F., Xu, Y., Ruiz, A. B., Chen, C. C., \& Spence, C. (2020). The Impact Of Peer Interactions On Language Development Among Preschool English Language Learners: A Systematic Review. Early Childhood Education Journal, 0123456789. https:// doi.org/10.1007/s10643-020-01126-5

Wulandari, D. I. (2018). Pemerolehan Bahasa Indonesia Anak Usia 3-5 Tahun Di PAUD LESTARI Desa Blimbing Kecamatan Paciran Kabupaten Lamongan. Lingua Franca:Jurnal Bahasa, Sastra, Dan Pengajarannya, 2(1), 74-83. https:// doi.org/10.30651/lf.v2i1.1346

Xu, Y., Chen, C. C., Spence, C., Washington-Nortey, M., Zhang, F., \& Brown, A. (2021). Supporting Young Spanish Speaking English Learners Through Teacher Scaffolding And Reciprocal Peer Tutoring. Early Child Development and Care, 0(0), 1-13. https:// doi.org/10.1080/03004430.2021.1874944

Yellamsetty, A., \& Bidelman, G. M. (2019). Brainstem Correlates Of Concurrent Speech Identification In Adverse Listening Conditions. Brain Research, 1714(February), 182192. https:// doi.org/10.1016/j.brainres.2019.02.025

Zein, S., Sukyadi, D., Hamied, F. A., \& Lengkanawati, N. S. (2020). English Language Education In Indonesia: A Review Of Research (2011-2019). Language Teaching, 53(4), 491-523. https://doi.org/10.1017/S0261444820000208

Zhang, C., \& Bingham, G. E. (2019). Early Childhood Research Quarterly Promoting HighLeverage Writing Instruction Through An Early Childhood Classroom Daily Routine ( WPI ): A Professional Development Model Of Early Writing Skills. Early Childhood Research Quarterly, 49, 138-151. https://doi.org/10.1016/j.ecresq.2019.06.003

Zhang, L. J., \& Shen, Y. (2020). Book review. System, 93, 102291. https://doi.org/10.1016/j.system.2020.102291 